\title{
Study on Current Condition and Existing Problems and Solutions about International Trade Department of Independent Institute
}

\author{
Xiaoyan Liu ${ }^{1}$ \\ Great Wall College \\ China University of Geosciences \\ Baoding, Hebei, China, 071000 \\ e-mail: 281750814@qq.com
}

\author{
Yanlong Pang ${ }^{2}$ \\ Hebei University \\ Baoding, Hebei, China 071002
}

\begin{abstract}
The independent institute, whose development has been paid much attentions by many parties since it's establishment, constantly improves it's major offer. At present, the major has been set up in many independent institutes, but the development of the major in different institutes is specific. This paper analyzed the developing conditions of the major firstly, then, analyzed obstacles in the cause of development in detail, finally came up with some proposals for the development of international trade department of independent institute, wishing to make contributions to it.
\end{abstract}

Keywords-independent institute; international trade department; teachers' ability; curriculum provision

\section{INTRODUCTION}

Independent institute was set up in1990s at the approval of ministry o education and then began its development, there are 291 independent institutes approved till June, 2013 to educate most bachelors of the nation, becoming one of the most important power of higher education of China. Independent institute was defined as the second class institutes at the undergraduate level that set up by undergraduate universities in a new system and new way.

In 2008, the official definition of independent institute was the higher education college that Implementation of bachelor degree or above education of common colleges and universities cooperation with social organizations or individuals other than state institutions, with the implementation of the non-state financial funds to hold bachelor degree education of institutions of higher learning ". As a new kind of education pattern, it endeavors to be as standard as public higher education university gradually in major offering even just has been developed for a short time, their majors become more and more perfect and complete. As a major with great development potential in current society, the major international economy and trade has been accepted by most of the independent institutes, so many such institutes set up this major and pay much attention to it's development, thus makes the major have a certain scale, however, during the development, there also emerges some new problems needed to be solved later.

\section{CURRENT CONDITIONS OF INTERNATIONAL TRADE DEPARTMENT IN INDEPENDENT INSTITUTES}

Having been developed for many years, the major international economy and trade formed it's own characteristics in curriculum provision, teaching staff and training objectives.

\section{A. Excellent Teaching Staff}

The years after the independent institute existence saw the jump of the number of postgraduate student of China, so most independent institutes require master degree or above when they recruit teachers. However, the major international economy and trade is different from the other economic majors, because it requires strong practical ability and teaching ability other than degree. Many institutes attach great importance to this point, and this makes the quality of teaching staff of this major better than others: the young teachers with a high degree count much, the proportion of teachers with practical ability is high, and a great many teachers are major in international economy and trade when they are undergraduates and postgraduates. This guaranteed the training of practical talents for the independent institutes.

\section{B. Distinct Training Objectives from that of Ordinary Institutions of Higher Learning}

Ministry of Education issued Some Proposals to Specify and Strengthen the Management on Trial Operation of Independent Institutes for the Ordinary Institutions of Higher Learning with New System and Mode in 2003, this paper pointed out that major offer in independent institutes should mainly meet the need of local and regional society and economic development, especially should endeavor to make conditions for those urgently needed in accelerating the development of society and human resource market. From this we can see that our nation require the independent institutes to cultivate compound and practical senior talents with high quality. Many independent institutes could reach the requirement of Ministry of Education and have clear goals in setting up majors, and training their students to be practical and qualified. China University of Geosciences 
Great Wall College oriented their students major in international economy and trade talent with high quality and practical ability. This kind of talents is substantially different from those of ordinary institutions of higher learning, especially those from tier one or tier two colleges.

\section{Reasonable Curriculum Provision}

As many other Public colleges and universities, the Curriculum Provision of international economy and trade also includes 5 parts: common basic courses, professional basic course, Professional core course, Professional elective course and public elective course. Being a major, what is most important is the provision of Professional core course and Professional elective course. Independent institutes refer to other Public colleges and universities when setting up courses of international economy and trade, such as $A n$ Introduction to International Trade, Practice of International Trade, International Finance, Business Correspondence for Foreign Trade, English in Economic and Trade Major, International Settlements, International Economics, International Laws of Business and so on; professional elective course such as International Commercial Arbitration and Litigation, Introduction to World Economy, Introduction to Chinese Foreign Trade, Electronic Commerce, etc. Internship and Practical Training contains during-course practice (experiment), comprehensive practice on international trade, graduation field work and Graduation Thesis. Independent institutes want to cultivate practical talents so they set up more courses than public colleges and universities. Such teaching arrangement both helps students combine theory and practice better and helps to fulfill the goal of training practical talents.

\section{EXISTING PROBLEMS IN THE DEVELOPMENT COURSE OF INTERNATIONAL TRADE DEPARTMENT OF INDEPENDENT INSTITUTES}

\section{A. Training Objective Not Embodied Completely in the Curriculum Provision}

According to the requirement of Ministry of Education, most of this majors in independent institutes regard the cultivation of practical talents as the teaching goal, however, many institutes' curriculum provision doesn't fully serve it because they didn't set up enough practice class and the proportion of practical teaching hours is shorter than given hours. They take theory teaching as principle thing, and begin this class in the sophomore year or junior year with less requirement on content, which discount the effect of practice course.

In addition, they have no specific research directions, and short of its own feature. This major is strongly comprehensive because it involves trade, finance, commerce, logistics and so on. Well, the Curriculum Provision of the independent institutes does not divide into several directions, so their students have no special skills and features even they are taught a lot.

\section{B. Poor Practical Experience of Teachers}

Teachers play a decisive role in teaching of the institutes, even institutes have paid attention to practice experience when they recruit teachers, and because of short history, their teaching faculty is relatively poor. The teaching staff composes of full-time teachers and part-time teachers, among the full-time teachers, most of them are young, so they can not form the "experienced, middle, inexperienced" teaching ladder, what's worse, many young teachers are current year's graduates with no work experience in the foreign trade department, so they have little teaching ability, pay too much attention to theory. While the part-time teachers mainly come from affiliated colleges and surrounding universities, though do they have teaching experience, they could not correctly understand training objective and training mode of independent institutes, they teach randomly, which is not conform to the requirement, as a result, the students are not satisfied with them.

Apart from the above, as a major requiring strong practical ability, the teachers must be equipped with great operating abilities, they had better to be "double-teacher", but such teachers are extremely rare or even no. This makes the class pale, not vivid, so students could not combine theory with practice very well.

\section{Poor Employment Competitiveness of Graduates}

Unemployment has to be a social problem. According to figures from Human resources and social security show that there were 6.1 million new graduates in 2009, 6.3 million in 2010, and 6.6 million in 2011. Under this situation, students from international economy and trade of independent institutes have even poor competitiveness. While companies give high demand on their employees, they have no patience to train these graduates and have no time or power to teach them. Thus, even independent institutes take cultivating practical talents as the goal, result from the limited practice conditions, students have no chance to put theory into practice, in turn, they have no competitiveness to find a good job.

\section{PROPOSALS ON FURTHER DEVELOPMENT OF INTERNATIONAL TRADE DEPARTMENT OF INDEPENDENT INSTITUTES}

\section{A. Setting up Courses according to Training Objectives}

The major belongs to Applied Economics, its goal is to cultivate practical talents. In order to make the goal come true, make the students become qualified persons of international economy and trade, the institutes should set up strong transactional courses, and encourage their students get relevant certificate, such as international commercial documents, Customs declaration certificate, Business English certificate, Inspection certificate, which help students master professional knowledge better and assist them to be qualified talents in this field. Independent institutes combine class with certificate, set up more helpful courses to get relevant certificate. So far, many institutes have set up practice of The Practices of International Trade, 
Introduction to Chinese Foreign Trade, Practices of Documents for Foreign Trade, English in Economic and Trade Major. These courses help students greatly in getting relevant certificate.

\section{B. Changing Professional Teachers Structure and Improving Teaching Level}

To change the teaching structure, first, independent institutes should introduce some experienced talents, concentrate on practical ability, do not regard degree as the only factor when recruiting teachers, second, they should encourage teachers to do part-time jobs in foreign trade enterprises in spare time to add double-teachers' number, only when teacher are equipped with ability to combine theory with practice can they foster highly educated students. At last, institutes should make conditions for teachers to study further, give teachers more opportunities to attend national or international meeting, they can also invite some experts in Foreign trade companies and Customs to give lectures so that they can expand information exchange, helps teachers know international information and trends, keep up with times, improve their professional quality.

\section{Making Full Use of Intramural and External Resources to Promote Students' Competitiveness}

Independent institutes should make better use of intramural and external-campus resources to improve students' competitiveness. First of all, they should perfect intramural experiment conditions, give students chance to practice. China University of Geosciences Great Wall College has established Economic comprehensive laboratory that can accommodate 90 students, they can simulate foreign trade company in the laboratory to practice themselves, combine theory with practice better; then, institutes should take full advantages of external-campus practice base and offer opportunities to students to practice in relevant institutions,. At present, although do many universities have practice base on paper, even none of them are at use if institutes want to improve competitiveness of their students, they must make better use of practice base, make students have access to practical operation, at least students are not green-hands. This requires institutes to utilize practice base actually but not on paper, finally, institutes should help students to enter them for an examination qualification certificate. Practice demonstrates that students with relevant certificates have more competitive advantages in society. Although do many institutes have set up related courses relevant certificates, parts of student are willing to attend such test, they struggle individually. At this moment, institutes should organize to offer "logistical support" for students.

\section{REFERENCES}

[1] Zhang Liping. Research on employment competitiveness of students from internationaltrade[J].administrator, 2013 (10)

[2] Talent training scheme of international economy and trade of Great Wall College of China University Geosciences (2013 version)
[3] Li Guoying,Yang Shengyou. Analysis on current teaching situation and countermeasure about international trade department of independent institute [J].Journal of Guangxi university(philosophy and social science edition), 2011.6 